\title{
METODE PENDIDIKAN ORANG TUA KEPADA ANAK (STUDI PADA ORANG TUA ANAK DI GANG ORI II PAPRINGAN SLEMAN YOGYAKARTA)
}

\author{
Imam Hanafi, Eko Adi Sumitro \\ Universitas Wiraraja Sumenep Jawa Timur \\ imamhanafi@wiraraja.ac.id, ekoadisumitro@wiraraja.ac.id
}

\section{Abstrak}

This study tries to examine the educational methods applied by parents to children in one alley in the Yogyakarta Region, with Gang Ori II Papringan Sleman Yogyakarta as a location. Using a qualitative naturalistic approach with descriptive analysis methods. Data collection is done by participant observation, in-depth interviews, and documentation. The data obtained were analyzed using Non-Statistical Spradley analysis. The results of this study indicate that based on the above explanation it can be concluded that, parents who live in Gang Ori II Papringan Sleman Yogyakarta vary in terms of the method of educating their children. There are those who educate their children with exemplary methods, there are also those who use the method of advice or customs. And some also use the method of punishment or sanctions. Kata Kunci: Metode Pendidikan, Anak, Orang Tua, Sleman

\section{A. PENDAHULUAN}

Dalam Islam, selain merawat dan membesarkan anak, para orang tua memiliki tanggung jawab yang sangat besar karena anak dipandang sebagai titipan dari Allah yang kelak akan dimintai pertanggung jawabannya. Selain 
itu, anak juga akan menjadi aset bagi orang tua di hari akhir kelak. Jika orang tua berhasil membesarkan anak dan mendidik anak menjadi anak yang sholih, maka ia akan menjadi syurganya para orang tua. Sedangkan jika gagal maka ia akan menjadi neraka bagi orang tua.

Dalam rangka membentuk anak yang shalih dan shalihah, Islam sudah memberikan atau meletakkan tata cara yang baik untuk pembinaan jiwa anak mulai anak itu dilahirkan. Tata cara tersebut misalnya disunnahkannya bagi bapak untuk mengumandangkan adzan dan iqomah saat bayi lahir. Biasanya adzan diperdengarkan ditelinga kanan anak dan iqoma ditelinga kiri. Setelah itu yang menjadi tanggung jawab orang tua yang pertama dan paling utama ialah melarang anak untuk musyrik.

Hal tersebut Allah firmankan dalam Al-Qur'an surat Luqman ayat 13, yang berbunyi:

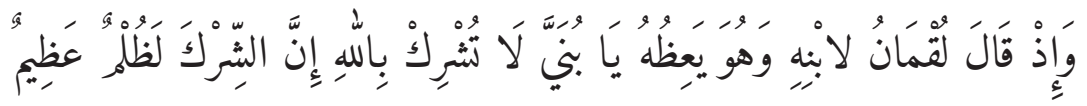

Artinya: Dan (ingatlab) ketika Luqman berkata kepada anaknya, di waktu ia memberi pelajaran kepadanya: "Hai anakku, janganlah kamu mempersekutukan Allah, Sesunggubnya mempersekutukan (Allah) adalah benarbenar kezaliman yang besar."

Selain itu, orang tua memiliki kewajiban untuk mengajarkan anak shalat. Akan tetapi perlu digaris bawahi bahwa dalam memberikan pengajaran kepada anak haruslah dimulai dari orang tua dulu yang melakukannya dan mempraktikkannya dalam kehidupan sehari-hari. Karena apapun yang dilakukan oleh orang tua, kecenderungan untuk meniru perilaku orang tua sangatlah besar.

Menurut hemat peneliti, secara garis besar tugas orang tua terdiri dari dua hal yakni: merawat dan memberikan bekal anak yang saat ini masih hidup di dunia, serta bekal untuk kelak hidup di akhirat. Disamping kebutuhan fisiknya yang terpenuhi, untuk menunjang keberhasilan anak hidup di dunia maka pendidikan orang tua berkontribusi besar terhadap itu.

Untuk mewujudkan hal tersebut, maka para orang tua harus tahu bagaimana mendidik anak yang sesuai dengan ajaran Islam. Orang tua harus mampu menguasai terhadap beberapa metode pendidikan anak serta pedoman-pedomannya agar anak bisa tumbuh dan berkembang menjadi pribadi yang shalih dan shalihah. Hal ini dikarenakan pada saat ini masih banyak para orang tua

${ }^{1}$ Al Mujib, Al-Qur'an dan Terjemahannya (Bandung: Almizan, 2010). 
yang salah kaprah dalam mendidik anak-anaknya. Misalnya mendidik anak dengan memukul jika anak melakukan kesalahan, padahal kesalahannya hanya sepele.

Terdapat banyak metode yang bisa diterapkan oleh para orang tua dalam mendidik anak dan membantu setiap kesulitan yang dialami oleh sang anak yang secara Islami. Seperti mendidik anak dengan keteladanan, dengan kebiasaan, dengan nasihat, dengan pengawasan, serta mendidik anak dengan cara hukuman. ${ }^{2}$ Dalam melasanakan metode tersebut, para orang tua haruslah berpegang teguh pada pedoman-pedoman yang telah ditentukan dalam Islam, misalnya ikhlas, takwa, santun, dll.

Seiring dengan perkembangan zaman, secara umum banyak kita temukan anak yang berbuat hal-hal yang berperilaku menyimpang. Misalnya seperti mencuri, sering berkelahi, atau mengeluarkan kata-kata yang tidak senonoh. Terdapat dua kemungkinan mengapa hal tersebut bisa terjadi, pertama karena tidak adanya pendidikan yang terarrah dari orang tua sehingga anak tidak memiliki contoh, kedua faktor teman atau lingkungan dimana anak tersebut berada. Inilah yang menjadi tantangan bagi para orang tua dalam mendidik anak supaya dia bisa menjadi orang yang baik, shalih dan shalihah sesuai dengan tuntunan Islam.

\section{B. PENDIDIKAN ANAK}

Seperti telah kita ketahui bersama bahwa pada hakikatnya pendidikan merupakan tanggung jawab para pendidik khususnya para orang tua dalam mendidik anak-anak mereka baik pendidikan yang berkenaan dengan aqidah, moral, maupun pendidikan sosial.

Tanggung jawab tersebut merupakan tantangan bagi para orang tua untuk mendidik anak mereka dan mempersiapkan dengan baik anak-anak mereka agar tidak salah memilih jalan nantinya. Konsekuensi yang dimunculkan dari beratnya tanggung jawab ini ialah tuntutan terhadap konsistensi sikap dalam perasaan-perasaan mereka, harus selalu menyayangi anak-anak mereka, harus menerima dan toleran tanpa syarat, harus adil, harus mendahulukan kepentingan anak, dan yang paling berat adalah tidak boleh membuat kesalahankesalahan yang dilakukan dalam mendidik anak mereka. ${ }^{3}$

\footnotetext{
2 Abdullah Nashih Ulwan, Pendidikan Anak Menurut Islam, Kaidah-kaidah Dasar (Bandung: Remaja Rosda Karya, 1992), 1.

3 Thomas Gordon, Menjadi Orang Tua Efektif (Jakarta: PT. Gramedia Utama, 1991), 12.
} 
Disamping itu, untuk mewujudkannya para orang tua dituntut untuk mencari metode yang tepat dalam rangka melaksanakan tanggung jawabnya untuk mendidik anak-anak mereka, dan ini haruslah dilakukan dengan sungguh-sungguh oleh para orang tua.

Terdapat beberapa metode mendidik anak yang dianggap sangat efisien dan memiliki pengaruh yang sangat besar yakni pendidikan dengan keteladanan, pendidikan dengan adat kebiasaan, pendidikan dengan nasihat, pendidikan dengan pengawasan, pendidikan dengan hukuman (sanksi). ${ }^{4}$

Pertama, Metode Pendidikan dengan Keteladanan. Keteladanan dalam pendidikan merupakan bagian dari beberapa metode yang dianggapa paling ampuh serta efektif dalam mempersiapkan dan membentuk anak baik secara moral, spiritual dan sosial. Pendidik dalam hal ini orang tua merupakan contoh ideal bagi seorang anak yang kesemuanya akan selalu ditiru oleh anak sekaligus akan melekat pada diri anak dan perasaanya.

Keteladanan merupakan faktor penentu baik dan buruknya seorang anak. Jika orang tua dalam kesehariannya menunjukkan sikap yang baik seperti jujur, berakhlak mulia, dan sifat mulia lainnya maka kemungkinan besar anak akan tumbuh dan berkembang dengan sifat-sifat tersebut.

Jika kita pahami lebih lanjut, inti dari keteladanan ialah proses meniru. Dari proses meniru inilah akan menjadi metode yang sifatnya konservatif (melestarikan). Orang tua yang memberikan keteladanan berupa perilaku yang terpuji terhadap anaknya, maka perilaku tersebut akan tetap ada dan hidup bersama dengan anak itu dalam bentuk yang persis sama. ${ }^{5}$ Metode keteladanan oleh Muhammad Quthb dianggap mampu menegtuk Sanubari Manusiawi dan sanggup mempengaruhi relung kesadarannya. ${ }^{6}$

Salah satu manusia yang sukses menerapkan metode keteladanan ini ialah nabi Muhammad SAW. Sebagaimana firman Allah dalam Al-qur'an surat AlAhzab ayat 21, yang berbunyi:

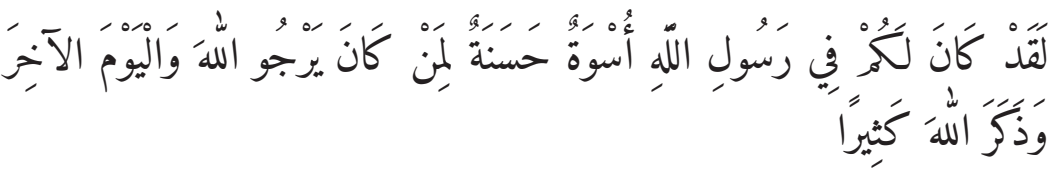

4 Ulwan, Pendidikan Anak Menurut Islam, Kaidah-kaidah Dasar, 1.

5 Azizah Munawwaroh, Keteladanan Sebagai Metode Pendidikan Karakter, Jurnal Penelitian Pendidikan Islam, 2019.

6 Rahendra Maya, Pemikiran Pendidikan Muhammad Quthb Tantang Metode Keteladanan (AlTarbiyah Bi al-Qudwah, Jurnal Pendidikan Islam, 2017. 
Artinya: Sesunggubnya telah ada pada (diri) Rasulullah itu suri teladan yang baik bagimu (yaitu) bagi orang yang mengharap (rahmat) Allah dan (kedatangan) hari kiamat dan Dia banyak menyebut Allah.?

Nabi Muhammad merupakan insan paripurna yang layak untuk dijadikan teladan dalam setiap aspek kehidapnnya, mulai dari kehidupan dunia maupun kehidupan akhirat. Terdapat banyak sekali kisah yang menunjukkan bagaimana seharusnya manusia berperilaku.

Dalam hal pendidikan, terdapat suatu kisah yang bisa diambil ibrah-nya oleh manusia ialah kisah yang terdapat dalam hadist yang diriwatkan oleh Abu Dawud dan Baihaqi, dan Abdullah bin Amr. Intinya Rosulullah pada saat itu menganjurkan untuk menepati janji orang tua kepada anaknya. Jika tidak ditepati maka Rasulullah menganggapnya sebagai pendusta. ${ }^{8}$

Dari kisah tersebut dapat dipahami bahwa kita harus membiasakan anak untuk selalu berbuat baik dan dimulai oleh orang tua dengan mencontohkannya kepada anak tersebut. Pendidikan dengan keteladanan merupakan tiang penyangga dalam rangka meluruskan penyimpangan moral dan perilaku anak itu sendiri. Bahkan selain itu, pendidikan dengan keteladanan merupakan asas utama dalam meningkatkan kualitas anak menuju kemuliaan.

Kedua, Metode Pendidikan dengan Adat Kebiasaan. Setiap anak dilahirkan dalam keadaan fitrah. Akan tetapi sejak saat itu juga dimulailah peran pembiasaan, pengajaran, pendidikan, dalam menumbuh kembangkan fitrah tersebut. Terdapat dua kemungkinan yang akan terjadi terhadap perkembangan fitrah tersebut, kemungkinan itu dipengaruhi oleh lingkungan ia belajar.

Jika lingkungannya dalam hal ini orang tua sebagai sekolah pertama dan utama bagi anak selalu menanamkan nilai untuk selalu berbuat baik sesuai dengan ajaran Islam, maka anak tersebut akan tumbuh dengan baik. Sebaliknya jika lingkungannya buruk, maka buruklah perkembangan anak tersebut.

Dalam hal menanamkan nilai pembiasaan pada anak, Islam memberikan dua sandaran pokok akan hal itu, diantaranya: pertama pengajaran. Maksud dari pengajaran ini ialah pendekatan dalam aspek teoritis dalam upaya memperbaiki anak. Kedua Pembiasaan. Maksud dari pembiasaan ini ialah praktek nyata dalam kehidupan sehari-hari.

Terdapat beberapa contoh tentang bagaimana mengajarkan dan membiasakan anak berperilaku baik seperti anjuran rasul untuk mengajarkan

\footnotetext{
$7 \mathrm{Al}$ Mujib, Al-Qur'an dan Terjemahannya.

8 Ibid, 30.
} 
anak kalimat laa ilaha illa Allah. Selain itu Rasul juga menganjurkan kepada orang tua untuk mengajarkan rukun-rukun shalat ketika anak berusia tujuh tahun. Mengajarkan anak tentang hala dan haram serta mengajarkan anak untuk mencintai nabi mereka.

Pendekatan yang bisa digunakan dari metode pembiasaan ini ialah pendekatan Disiplin. ${ }^{9}$

Secara garis besar pendidikan dengan adat kebiasaan ini merupakan penunjang pokok pendidikan anak dan merupakan sarana dalam upaya menumbuhkan keimanan anak dan mencegah munculnya perilaku amoral anak.

Ketiga, Metode Pendidikan dengan Nasihat. Pendidikan nasihat ini merupakan salah satu cara dari beberapa cara yang paling ampuh bagi para pendidik dalam hal ini orang tua khususnya. Hal ini dikarenakan nasihat memiliki peran yang sangat besar dalam rangka menjelaskan kepada anak tentang hakikat, akhlak mulia, dan mengajarinya prinsip-prinsip yang berlaku dalam Islam. Jadi tidak heran banyak sekali kisah dalam Al-Qur'an yang berisi tentang pendidikan dengan menasihati. Misalnya kisah Luqman yang menasihati bapaknya untuk tidak menyekutukan Allah.

Mengenai gaya bahasa yang biasa digunakan oleh Rasulullah dalam memberikan nasihat sangatlah kaya dan beragam, seperti dengan bercerita, berdialog dengan menggunakan tanya jawab, memulai nasihat dengan diawali bersumpah kepada Allah, menasihati dengan berkelakar atau bercanda, nasihatnya sangat sederhana sehingga tidak membosankan, nasihat yang membakar semangat, nasihat dengan memberikan contoh, nasihat tamsil dengan tangan, nasihat dengan rumus dan penjelasan, nasihat dengan praktek langsung, serta masih banyak lagi metode Rasul dalam memberikan nasihat. ${ }^{10}$ Selain itu bentuk dari nasihat bisa berupa peringatan, sebagaimana Allah dalam firmannya selalu menyinggung akan manfaat dari peringatan tersebut, sebagai contoh bentuk peringatan Allah dalam QS. Qaaf ayat 37. ${ }^{11}$

Keempat, Metode Pendidikan dengan Pengawasan. Yang dimaksud pendidikan dengan pengawasan ialah pendampingan terhadap anak dalam kesehariannya dalam rangka membentuk moral, mengawasinya

9 Siti Saidah, Metode Pendidikan Bagi Pengembangan Rasa Agama Pada Anak Usia Awal" Jurnal Pendidikan Agama Islam, 2005.

${ }^{10} \mathrm{Ibid}, 65$.

${ }^{11}$ Amin Zamroni, Strategi Pendidikan Akblak Pada Anak, Jurnal SAWWA, 2017. 
dalam mempersiapkan anak baik secara psikis maupun sosial, dan kepo terhadap keadaan anaknya baikmdalam pendidikan jasmani maupun dalam belajarnya.

Terdapat banyak sekali nash Al-Qur'an yang berkaitan dengan pengawasan ini, salah satunya seperti firman Allah dalam Al-Qur'an surat At-tahrim ayat 12, yang berbunyi:

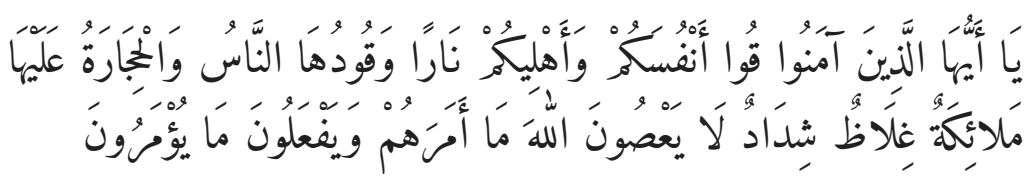

Artinya: Hai orang-orang yang beriman, peliharalah dirimu dan keluargamu dari api neraka yang bahan bakarnya adalah manusia dan batu; penjaganya malaikat-malaikat yang kasar, keras, dan tidak mendurhakai Allah terhadap apa yang diperintabkan-Nya kepada mereka dan selalu mengerjakan apa yang diperintabkan. ${ }^{12}$

Ayat ini memiliki pesan yang kuat agar para orang tua selalu memberikan pengawasan terhadap anak-anak mereka. Bagaimana seorang pendidik dalam hal ini orang tua akan mampu menjaga keluarga dan anak-anaknya dari api neraka jika dia tidak memerintah dan mencegah mereka dan tidak mengawasi mereka?

Nabi Muhammad senantiasa selalu memberikan contoh dan pemeliharaan yang sebaik-baiknya kepada para sahabat, mempertanyakan keadaan mereka, memberi peringatan kepada yang lalai, memeberi semangat kepada yang berbuat baik, bersikap lembut kepada para fakir miskin, mendidik anak kecil dengan telaten, serta mengajari yang jahil.

Selain itu pengawasan nabi mencakup seluruh aspek kehidupan manusia, mulai dari pendidikan sosial, hukum halal haram, mendidik anak kecil, memberi petunjuk bagi orang dewasa, mengawasi pendidikan moral, pendidikan psikis, pendidikan jasmani, dakwah, perhatian terhadap moral anak, jiwa anak, fisik anak, serta aspek spiritualitas anak.

Kelima, Metode Pendidikan dengan Hukuman (Sanksi). Secara universal, terdapat hukum-hukum syariat yang lurus dengan prinsip yang bertujuan memelihara kebutuhan asas yang harus dipenuhi oleh manusia. Jika hal tersebut dilanggar maka sanksi boleh dijatuhakan kepada anak sesuai dengan batasan yang telah ditetapkan dalam Islam.

${ }^{12}$ Al Mujib, Al-Quran dan Terjemahannya. 
Terdapat beberapa sanksi yang bisa diterapkan oleh pendididk dalam hal ini orang tua di rumah, dimana sanksi tersebut berbeda dengan sanksi-sanksi yang umum diterapkan di masyarakat. Adapun metode yang telah diterapkan dalam Islam tersbut diantaranya: a) Memperlakukan anak dengan penuh kelembutan dan kasih sayang, misalnya dengan memberikan mereka pengertian, b) Memberi sanksi kepada anak yang salah, walaupun terdapat beberapa tokoh muslim yang melarang menjatuhkan sanksi kecuali sudah sangat terdesak dan betul-betul dibutuhkan, c) Mengatasi dengan bertahap, dimulai dari yang paling ringan sampai kepada yang paling berat.

Seperti yang telah dilakukan nabi dalam rangka memperbaiki kesalahan anak, misalnya dengan memberitahukan kesalahan anak disertai dengan bimbingan, menyalahkan dengan lembut, menyalahkan dengan isyarat, menyalahkan dengan menjelekkan, memperbaiki kesalahan dengan meninggalkan anak pergi, memperbaiki kesalahan dengan memukul, serta menyadarkan kesalahan anak dengan sanksi yang keras.

Perlu ditekankan bahwasanya hal tersebut haruslah bertahap, walaupun nabi menganjurkan memukul akan tetapi tahapan sebelumnya harus sudah dilewatkan.

\section{METODE PENELITIAN}

Dengan memperhatikan model dan kesenjangan yang telah diuraikan di atas, maka penelitian ini memakai pendekatan pendidikan. Pendekatan pendidikan dengan teori pendidikan anak dalam Islam peneliti gunakan untuk mengungkap beberapa metode yang digunakan oleh para orang tua dalam mendidik anak-anak mereka.

Maka dari itu, penelitian ini menggunakan metode dan pendekatan kualitatif naturalistik. Penelitian kualitatif adalah prosedur penelitian yang menghasilkan data deskriptif berupa kata-kata dan simbol-simbol bahasa tertulis dan lisan dari orang-orang dan perilaku yang dapat diamati. Sebagaimana pendapat Bogdan dan Biklen:

"We use qualitaive research as an umbrella term to refer to several researcch strategis that share certain characteristic. The data collected has been termed soft, that is, rich in description of people, place, and conversation, and not easily handled by statistical procedures. "... in education, qualitative research is frequently called "naturalistic" because the researcher hangs around where the events he or she is interested in naturally occur. And the data is gathered 
by people engaging in natural behavior: talking, visiting, looking, eating and so on."13

Melalui pendekatan kualitatif, diharapkan bisa mengetahui secara detail perkembangan anak yang tinggal di pondok pesantren cilik. Dengan langsung melakukan wawancara, observasi, dan dokumentasi akan membuat data yang dihasilkan semakin tinggi tingkat kepercayaannya.

Sumber data yang digunakan dalam penelitian ini terdiri dari dua sumber. Pertama, data primer. Merupakan data yang diperoleh langsung dari subjek penelitian sebagai sumber informasi yang dicari. Sedangkan data yang kedua, merupakan data sekunder yang diperoleh dari buku dan karya ilmiah terkait dengan metode pendidikan anak.

Sedangkan metode pengumpulan data yang digunakan dalam penelitian ini ialah: a) Observasi (pengamatan langsung). Observasi adalah kegiatan keseharian manusia dengan menggunakan panca indera mata sebagai alat bantu utamanya. Selain panca indera lainnya seperti telinga, ciuman, mulut dan kulit. ${ }^{14}$ Pengamatan (observasi) yang dimaksudkan disini adalah pemusatan perhatian dengan hanya mengamati terhadap jenis kegiatan dan peristiwa tertentu yang bisa memberikan informasi dan pandangan yang benar-benar berguna seperti jenis peristiwa, kegiatan, atau perilaku tertentu saja sesuai dengan fokus atau bagian dari masalah yang akan diteliti. Pada penelitian ini akan menggunakan observasi tak berstruktur dengan objek para aktor (pelaku). Metode ini digunakan untuk mendapatkan data berkaitan dengan metode pendidikan orang tua terhadap anaknya. b) Interview (Wawancara). Wawancara (interview) adalah percakapan dengan maksud tertentu. ${ }^{15}$ Pada penelitian ini akan menggunakan wawancara terstruktur, karena pewawancara dalam hal ini peneliti akan menetapkan sendiri masalah dan pertanyaan-pertanyaan yang akan diajukan. Metode wawancara digunakan untuk mendapatkan data berupa pernyataan para orang tua terkait dengan metode yang mereka terapkan dalam mendidik anak-anaknya.

Setelah data dikumpulkan, maka dilakukan analisis data. Analisis data adalah proses mengorganisasikan dan mengurutkan data kedalam pola, kategori, dan satuan uraian dasar sehingga dapat ditemukan tema dan dapat diru-

${ }^{13}$ Bogdan Robert C. \& Biklen Sari K, Qualitative Research for Edducation: an introduction to Theory and Methods (Boston: Ailyn and Bacon, 1982), 2.

${ }^{14}$ Burhan Bungin, Penelitian Kualitatif(Jakarta: Kencana Prenada Media Group, 2012), 117.

${ }^{15}$ Lexy J.Moloeng, Metodologi Penelitian Kualitatif(Bandung: PT. Remaja Rosda Karya, 2008), 186. 
muskan hipotesis kerja seperti yang disarankan oleh data. ${ }^{16}$ Analisis data yang akan peneliti gunakan dalam penelitian ini bersifat Non Statistik ${ }^{17}$ model Spradley. Yaitu penelitian yang menghasilkan data-data diskriptif berupa katakata tertulis atau lisan dari orang-orang melalui perilaku yang dapat diamati. ${ }^{18}$ Artinya yang di analisis hanya data yang telah diperoleh melalui metode observasi dan wawancara.

\section{PEMBAHASAN}

Pendidikan anak merupakan tanggung jawab para orang tua, dikarenakan rumah bagi anak dalam Islam ialah sebagai madrasah pertama dan paling utama. Disinilah anak akan meniru dan belajar banyak hal dari keluarga khususnya para orang tua.

Dalam mendidik anak, para orang tua harus berhati-hati, dikarenakan jika salah dalam merawat dan mendidik anak maka akibatnya akan sangat buruk baik kepada keluarga lebih-lebih pada anak itu sendiri. Maka dari itu orang tua harus paham betul bagaimana metode mendidik anak khususnya yang dianjurkan oleh nabi Muhammad SAW.

Menurut hemat peneliti metode yang dipakai oleh masyarakat pedesaan sedikit berbeda dengan masyarakat perkotaan. Berdasarkan observasi yang telah peneliti. Para orang tua yang tinggal di desa cenderung memberikan kelonggaran kepada anak berkaitan dengan waktu bermainnya, akan tetapi mereka tetap mendapat pendidikan dan pengawasan dari orang tua, sedangkan orang tua yang berada di daerah perkotaan tingkat proteksi kepada anak lebih besar, maklum lah bahaya ancaman bagi anak yang tinggal di kota mengintai di mana-mana sehingga anak lebih sering berada di dalam rumah setelah mereka pulang sekolah.

Akan tetapi terkadang metode yang dipakai sangatlah tidak tepat misalnya membelikan anak Hp Android dan tidak dilakukan pengawasan dalam penggunaannya, bermain Game Play Station yang tidak kenal waktu, dan lain sebagainya. Hal ini menurut hemat peneliti merupakan keadaan yang harus diperbaiki dikarenakan kebutuhan anak bukan hanya itu, pendidikan anak bukan hanya mereka terima ketika berada di kelas akan tetapi saat berada di

\footnotetext{
${ }^{16}$ Ibid, 280.

${ }^{17}$ Trianto, Pengantar Pendidikan Bagi Pengembangan Profesi Pendidikan dan Tenaga Kependidikan (Jakarta: Kencana Prenada Media Group, 2010), 180.

${ }^{18}$ Lexy Jl. Moleong, Metode-Metode Penelitian Kualitatif (Bandung: Remaja Rosda Karya, 1994), 3.
} 
rumah anak haruslah mendapat pendidikan juga dari para orang tua. Walaupun tidak dapat dipungkiri bahwa ada orang tua yang mendidik anaknya sesuai dengan metode yang dianjurkan oleh nabi.

Secara umum, anak-anak yang tinggal di daerah Papringan Gang Ori II Yogyakarta mengalami kesalahan metode mendidik yang dilakukan oleh para orang tua. Dari delapan anak asli penghuni gang ini hanya dua anak yang tidak memiliki Hp dikarenakan orang tuanya yang berstatus sebagai juru parkir. Sedangkan yang satunya adalah anak dari salah satu donatur terbesar utk pembangunan infrastruktur yang ada di gang ini.

Kondisi yang lebih memprihatinkan, anak-anak ini membawa $\mathrm{Hp}$ tersebut saat pergi ke masjid untuk shalat jamaah. Biasanya situasi ini bisa dilihat pada saat jamaah sholat maghrib. Sebagian dari mereka bukannya sholat akan tetapi malah bermain $\mathrm{Hp}$ di depan teras Masjid. ${ }^{19}$ Adapun metode pendidikan yang digunakan oleh orang tua anak di Gang Ori II Papringan Sleman Yogyakarta diantaranya: pertama, Metode dengan Keteladanan. Keteladanan merupakan salah satu metode yang tergolong ampuh dalam mendidik anak untuk menjadi generasi yang tumbuh dan berkembang dengan baik. Disini para orang tua haruslah mampu melaksanakan perbuatan tertentu agar bisa di tiru oleh sang anak. Berdasarkan hasil observasi yang dilakukan terhadap beberapa keluarga hanya ada tiga keluarga yang memakai metode ini, yakni keluarga OM (Juru parkir), keluarga RK (wiraswasta) dan MM (pengusaha/donatur).

Metode ini dianggap metode yang paling tepat dalam rangka membentuk kepribadian anak yang kuat, sabar, shalih dan shalihah sesuai dengan ajaran Islam. Tanpa memandang status keluarga itu sendiri baik itu kalangan keluarga dengan ekonomi yang mapan maupun keluarga dengan ekonomi keluarga yang pas-pasan.

Kedua, Pendidikan dengan Adat Kebiasaan. Pendidikan dengan adat kebiasaan ini pada hakikatnya hampir memiliki kesamaan dengan metode pendidikan dengan keteladanan. Hanya saja keteladanan itu terus di ulang-ulang sehingga mereka terbiasa dengan perilaku baik tersebut, Yang menjadi keprihatinan saat ini ialah kurangnya membiasakan anak-anak untuk berbuat baik tersebut. Hal ini dikarenakan oleh pola kebiasaan tersebut tidak bisa dipahami oleh salah satunya baik orang tua maupun anak. ${ }^{20}$

Kondisi inilah yang sering memperburuk keadaan dan cenderung meng-

\footnotetext{
${ }^{19}$ Observasi, Masjid Al-Hidayah Papringan Sleman Yogyakarta, 5-6 Januari 2017

${ }^{20}$ Maurice Balson, Bagaimana Menjadi Orang Tua yang Baik (Jakarta: Bumi Aksara, 1993),1.
} 
anggap sudah mendidik anak dengan benar. Contohnya seperti orang tua yang salah tanggap atas konflik yang terjadi antara anak dengan temannya sehingga orang tua ikut campur dan membuat keadaan semakin keruh. Padahal itu sudah lumrah terjadi di kalangan anak, maka dari itu orang tua harus mampu membiasakan diri dan memahami kondisi-kondisi seperti ini. Ada baiknya orang tua tidak perlu ikut campur, akan tetapi cukup menanyakan duduk persoalannya dan memberikan nasehat anak dengan baik.

Ketiga, Metode Pendidikan dengan Nasihat. Seperti telah kita ketahui bersama bahwasanya nabi sendiri memiliki banyak metode dalam memberikan nasihat itu sendiri, khususnya kepada anak. Akan tetapi faktanya di lapangan, kebanyakan anak acuh tak acuh terhadap orang tua mereka yang sedang menasehati mereka. Situasi ini harus segera diputus mata rantainya. Berdasarkan hasil pengamatan peneliti, keluarga ZE sering menasehati anak-anaknya. Kondisi ini hampir setiap hari dilakukan oleh ZE kepada anaknya namun tidak dihiraukan oleh anaknya. ${ }^{21}$

Keempat, Metode Pendidikan dengan Pengawasan. Orang tua yang memiliki tanggung jawab yang tinggi tidak akan pernah melepaskan anaknya dari pengawasan dirinya. Hal ini tidak lain dikarenakan mereka menyadari bahwa anak merupakan sebagian amanah yang akan dimintai pertanggung jawabannya kelak.

Memberikan pengawasan disini maksudnya ialah menyediakan kesempatan sebaik-baiknya kepada anak untuk menemukan minat, bakat, serta kecakapan-kecakapan lainnya serta mendorong anak agar meminta bimbingan dan nasehat. Mengawasi bisa juga dengan menyediakan informasi-informasi penting dan relevan yang sesuai dengan bakat dan minat anak. Selain itu mengawasi juga bisa dengan menyediakan fasilitas atau sarana belajar serta membantu kesulitan belajarnya. ${ }^{22}$

Mengawasi bukan berarti mengekang anak untuk berkreasi, atau mengekang anak dalam setiap aktifitas yang ingin dia lakukan. Tapi mengawasi adalah melakukan pendampingan dalam setiap aktifitas anak.

Meskipun demikian para orang tua tak selamanya akan bisa mendampingi anak-anak mereka dalam setiap aktifitasnya. Akan tetapi usahakan agar anak

${ }^{21}$ Peneliti melihat anaknya sering tidak menghiraukan setiap nasihat yang disampaikan oleh ZE dikarenakan ketidak seriusan dalam menasihatinya. Seperti menasihati sambil bermain $\mathrm{Hp}$, atau nasihat itu disampaikan sambil bergurau dengan anaknya.

${ }^{22}$ Arifin, Pokok-Pokok Pemikiran Tentang Bimbingan dan Penyuluhan Agama, (Jakarta: Bulan Bintang, 1992), 92. 
memiliki tempat yang nyaman untuk mereka berbagi atas setiap masalah dan kesulitan yang dia hadapi.

Hal-hal seperti inilah yang kadang sulit dimiliki oleh para orang tua. Seakan-akan mereka lepas tanggung jawab tanpa perasaan bersalah dan kelak akan dimintai pertanggung jawabannya atas dirinya dan keluarganya. Maka dari tiu orang tua yang baik adalah orang tua yang selalu berada di samping anak dalam setiap perkembangannya, tidak harus secara fisik. Akan tetapi bisa dengan cara non fisik, seperti dengan menelponnya, dll.

Kelima, Metode Pendidikan dengan Hukuman (sanksi). Memberikan hukuman kepada anak merupakan sesuatu yang sah-sah saja, hal ini dikarenakan anak merupakan amanah yang akan dimintai pertanggung jawabannya. Bahkan Islam sendiri menganjurkan untuk menghukum anak dalam beberapa situasi, misalnya dengan memukul anak saat usia 10 tahun ketika anak tidak mau mengerjakan shalat.

Akan tetapi, walaupun demikian Islam memberikan panduan yang jelas bagaimana orang tua seharusnya menghukum. Seperti yang telah disebutkan di atas hukuman itu harus dilakukan secara bertahap. Mulai dari hukuman yang paling ringan sampai pada hukuman yang paling berat.

Hal inilah yang kadang diabaikan oleh para orang tua. Kebanyakan para orang tua menghukum tidaklah sesuai dengan kesalahan yang diperbuat oleh sang anak. Hal inilah yang sering terjadi pada keluarga RK, SM, ZE, dan AH. Berdasarkan hasil data yang telah dikumpulkan khususnya observasi, secara umum ternyata latar belakang pendidikan keluarga ini masih sangat rendah, selain itu juga mereka merupakan pekerja buruh yang selalu pulang ke rumah dalam keadaan capek. Kondisi inilah yang menurut peneliti yang menjadi latar belakang kecenderungan mendidik anak-anak mereka dengan metode pendidikan dengan hukuman, namun metode yang mereka pakai masih jauh dari apa yang dianjurkan dalam Islam.

Keenam, Metode pendidikan dengan Reward (Hadiah). Metode ini dalam beberapa tulisan sedikit di abaikan, hal ini mungkin dikarenakan metode ini dalam prakteknya jarang ditemukan. Padahal metode ini sangatlah efektif dalam menguatkan tingkah laku yang dikehendaki baik untuk anak-anak maupun orang dewasa.

Bahkan dalam al-Qur'an sendiri Allah menggunakan metode ini dengan memberikan pahala kepada setiap kaum muslim yang melakukan amal shalih 
itu. ${ }^{23}$ Allah berfirman dalam al-Qur'an Surat al-qari'ah ayat 6-7, yang berbunyi:

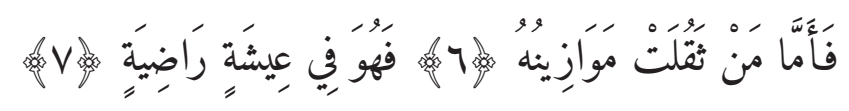

Artinya: Dan Adapun orang-orang yang berat timbangan (kebaikan)nya. Maka Dia berada dalam kehidupan yang memuaskan. ${ }^{24}$

\section{E. SIMPULAN}

Berdasarkan dari paparan di atas dapat disimpulkan bahwa, para orang tua yang tinggal di Gang Ori II Papringan Sleman Yogyakarta bervariasi dalam hal metode mendidik anak-anak mereka. Ada yang mendidik anak mereka dengan metode tauladan seperti yang dilakukan dalam keluarga MM, ada juga yang menggunakan metode nasihat ataupun adat kebiasaan. Serta ada juga yang menggunakan metode hukuman atau sanksi.

Latar belakang pendidikan, ekonomi, dan tingkat pemahaman agama menurut hemat peneliti memiliki keterkaitan yang sangat erat dengan setiap metode yang digunkan oleh beberapa keluarga yang tinggal di Gang Ori II Papringan Sleman Yogyakarta.

\footnotetext{
${ }^{23}$ Najah as Sabatin, Dasar-dasar Mendidik Anak Usia 1-10 Tahun (Bogor: Al-azhar Fresh Zone Publishing, 2014), 163.

${ }^{24}$ Al Mujib, Al-Qur'an dan Terjemahannya.
} 


\section{DAFTAR PUSTAKA}

Al Mujib. Al-Qur'an dan Terjemahannya. Bandung: Almizan, 2010.

Arifin. Pokok-pokok Pemikiran Tentang Bimbingan dan Penyuluban Agama.

Jakarta: Bulan Bintang, 1992.

Arikunto, Suharsimi. Manajemen Penelitian. Jakarta: Rineka Cipta, 2010.

As- Sabatin, Najah. Dasar-dasar Mendidik Anak Usia 1-10 Tahun. Bogor: alAzhar Freshzone Publishing, 2014.

Balson, Maurice. Bagaimana Menjadi Orang Tua Yang Baik. Jakarta: Bumi Aksara, 1993.

Bungin, Burhan. Penelitian Kualitatif. Jakarta: Kencana Prenada Media Group, 2012.

Erzad, Azizah Maulina, "Peran Orang Tua Dalam Mendidik Anak Sejak Dini Di Lingkungan Keluarga, , Jurnal ThufuLA : Jurnal Inovasi Pendidikan Guru Raudhatul Athfal, Vol. 5 No. 2 Juli - Desember 2017

Gordon, Thomas. Menjadi Orang Tua Efektif. Jakarta: PT. Gramedia Pustaka Utama, 1999

Maya, Rahendra. “Pemikiran Pendidikan Muhammad Quthb Tentang Metode Keteladanan (al-Tarbiyah Bi al-Qudwah), Jurnal Pendidikan Islam, Vol.6, No.11,Januari 2017,10.

Moleong, Lexy J. Metode Penelitian Kualitatif. Bandung: PT. Remaja Rosdakarya, 2004.

Munawwaroh, Azizah. "Keteladanan Sebagai Metode Pendidikan Karakter" Jurnal Penelitian Pendidikan Islam, Vol.7, No.2, 2019, 144.

Saidah, Siti. " Metode Pendidikan Bagi Pengembangan Rasa Agama Pada Anak Usia Awal” Jurnal Pendidikan Agama Islam, Vol.II, No.2, 2005, 251.

Robert C, Bogdan \& Biklen Sari K. Qualitative Research for Edducation: an Introduction to Theory and Methods. Boston: Ailyn and Bacon, 1982.

Trianto. Pengantar Penelitian Pendidikan Bagi Pengembangan Profesi Pendidikan dan Tenaga Kependidikan. Jakarta: Kencana Prenada Media Group, 2010.

Ulwan, Abdullah Nashih. Pendidikan Anak Menurut Islam, Kaidah-Kaidah Dasar. Bandung: PT. Remaja Rosdakarya, 1992. 
Zamroni, Amin. "Strategi Pendidikan Akhlak Pada Anak" Jurnal SAWWA, Vol.12, No.2, April 2017, 257. 